\title{
Evaluation of antibacterial activity of "Mangabarana" Austroplenckia populnea Reissek (Celastraceae)
}

\author{
Roqueline R. S. de Miranda, ${ }^{1}$ Lucienir P. Duarte, ${ }^{1}$ Grácia D. F. Silva ${ }^{*, 1}$ Sidney A. Vieira \\ Filho, ${ }^{1,2}$ Paulo B. de Carvalho, ${ }^{3}$ Ana Cristina Messas ${ }^{3}$ \\ ${ }^{1}$ Departamento de Química, Universidade Federal de Minas Gerais, Av. Antônio Carlos, 6627, 31270-901 \\ Belo Horizonte-MG, Brazil, \\ ${ }^{2}$ DEFAR, Escola de Farmácia, Universidade Federal de Ouro Preto, Rua Costa Sena, 17, \\ 35400-000 Ouro Preto-MG, Brazil, \\ ${ }^{3}$ Departamento de Microbiologia e Imunologia, Universidade do Oeste Paulista, Rua José Bongiovani, 700, \\ 19050-900 Presidente Prudente-SP, Brazil
}

\begin{abstract}
RESUMO: "Avaliação da atividade antibacteriana de "Mangabarana" Austroplenckia populnea Reissek (Celastraceae)". Austroplenckia populnea (Mangabarana) é popularmente utilizada em Minas Gerais, Brasil, para o tratamento de disenterias. A ela também são atribuídas propriedades antitumoral e antiúlcera. Extratos de partes desta planta obtidos com solventes de diferentes polaridades e triterpenos pentacíclicos (TTPCs) isolados destes, por métodos fitoquímicos foram submetidos a testes de atividade antibacteriana. Os resultados mostraram a existência desta atividade e abriram perspectivas para a continuidade dos estudos com outros compostos orgânicos isolados desta planta.
\end{abstract}

Unitermos: Austroplenckia populnea, Celastraceae, atividade antibacteriana, triterpenos pentacíclicos.

\begin{abstract}
Austroplenckia populnea (Mangabarana) is popularly used by people from Minas Gerais, Brazil for dysenteries diseases treatment. Antitumor and antiulcer activities were also attributed to this plant. Extracts obtained using solvents of different polarities and pentacyclic triterpenes (PCTTs) isolated from these extracts through phytochemical methods were submitted to antibacterial assays. The results showed the existence of this activity and open perspectives for news studies with other organic compounds isolated from this plant.
\end{abstract}

Keywords: Austroplenckia populnea, Celastraceae, antibacterial activity, pentacyclic triterpenes.

\section{INTRODUCTION}

The indiscriminate use of antibiotics has been caused bacterial resistance, allergic sensibility, blocking of natural fermentation processes and other adverse biological effects. This fact induces the development of new antibiotics with a good efficacy and with low incidence of adverse effects.

Ethnobotanical and ethnopharmacological studies have shown that products obtained from plant can present healing action related to specific pathologies. Consequently, a great variety of medicinal plants have been investigated to evaluate and validate their real biological activity (Cardoso and Santos, 1948; Kinghorn and Balandrin, 1993; Rao, 1996; Gnan and Demello, 1999; Hernandez et al., 2000; Deena et al., 2000; Cardoso-Lopes et al., 2008). The use of plants and their derivatives for different diseases occurs since the beginning of the humanity (Antunes et al.,
2006). With the advances of pharmaceutical industries, mainly after World War II, the use of herbal medicines diminishes in function of the dissemination idea of its inefficiency (Antunes et al., 2006). However, the efficacy and trustworthiness in medicinal plant products have demonstrated the real value of these materials. Brazil have a great diversity of native plants (Mors, et al., 2000, Barbosa-Filho, et al., 2005, Brandão, et al., 2006; Quintans-Júnior et al., 2008), but its medicinal properties had had not been adequately studied yet. The scientific study of plants used in folk medicine is essential to lower the adverse effect risk for populations (Agra et al., 2008).

Frequent deforestation and fires are threatening a substantial number of native plant species with extinction. The Autroplenckia populnea Reissek, specie of the Celastraceae family is among of them. This plant, commonly known as "Mangabarana", "Marmelodo-campo" or "Mangabeira-brava", can be found in a 
vast tropical ecoregion known as "Cerrado" mainly in the State of Minas Gerais, Brazil, and has been of great interest to researchers because of its chemical constituents, larvicidal effect, and molluscicidal effect (Vichnewski et al., 1984).

Other biological activities were also attributed to Austroplenckia populnea including antidysenteric action (Correa, 1969), antitumoral action (Monache, 1972) and antirheumatic action (Gonzalez et al., 1982). In relation to the dysenteries, it is important to point out that epidemiological studies indicate high E. coli prevalence, mainly in people who live in Brazilian cities peripheries (Tavares-Dias \& Grandini, 1999), and, are exactly these people that use A. populnea and other medicinal plants more frequently. Previous studies demonstrate antibacterial activity of the following pentacyclic triterpenes (PCTTs) isolated from Austroplenckia populnea: abruslactone-A, 3-epiabruslactone-A, populnilic acid, polpuninic acid and katononic acid (Vieira Filho et al., 1999). Treatment of adult Wistar rats with hexane extract obtained from dried Austroplenckia populnea leaves showed an antispermatogenic action characterized by a significant decrease of the epididymis spermatozoa number (Mazaro et al., 2000). Anti-Trypanossoma cruzi effect presented by the PCTTs epikatonic acid and 20-hydroxy-tingenone isolated from A. populnea was also related (Duarte et al., 2002).

The isolation and identification of other PCTTs, sesquiterpenes and other chemical constituents from this specie have been reported by several authors (Monache, 1972; Vichnewski et al., 1984; Souza et al,. 1988; Souza et al., 1990; Silva et al., 2002; Vieira Filho et al., 1999; Vieira Filho et al., 2000; Vieira Filho et al., 2001; Cotta et al., $1990 \mathrm{a}, \mathrm{b}$ ).

The objectives of this work involve the antibacterial evaluation of the A. Populnea extracts obtained using solvents of different polarities and the PCTTS isolated from them, followed by determination of the minimum inhibitory concentration (MIC), and by the minimum bactericidal concentration (MBC). Because of the previous antibacterial effect identified for some PCTTS (Vieira Filho et al., 1999) and the popular use of the decoct from A. Populnea branches as an antidysenteric (Correa, 1969), the PCTTS friedelin (1), 3ß-friedelinol (2), 28-hydroxyfriedelin (canofilol) (3), populnonic acid (4), katononic acid (6), epikatonic acid (8), pristimerin (10), abruslactone A (11) and $\alpha$-amirin (12) isolated from Austroplenckia populnea and the transformation products: methyl populnonate (5), methyl katotonate (7) and methyl epikatonate (9) (Figure 1) were tested to determine the in vitro bacterial activity.

\section{MATERIAL AND METHODS}

\section{Plant}

A. Populnea was collected in the proximities of Miguelão Lake, at Nova Lima city region, Minas Gerais, Brazil. This plant was identified by Prof. Wagner Pedersoli (in memoriam). A sample of the collected material was compared and identified with a voucher specimen ( $\mathrm{N}^{\circ} 10473$ ) deposited at the Herbarium of the Natural History Museum of Universidade Federal de Minas Gerais, Belo Horizonte, Minas Gerais, Brazil.

\section{Extracts obtainment}

Leaves, branches, (bark and heartwood) and root were separated and dried over kraft paper at room temperature. After fragmentation on a mill, each part was submitted to continuous extraction process in a Soxhlet apparatus using hexane, chloroform, ethyl acetate, methanol and $n$-butanol as solvent extractor.

Afterwards, each extract was submitted column chromatography (CC), flash-CC, high-pressure liquid chromatography (HPLC) and other phytochemical methods. By these processes it was possible to isolate the PCTTs: friedelin (1), 3 $\beta$-friedelinol (2), 28-hydroxyfriedelin (canofilol) (3), populnonic acid (4), catononic acid (6), epikatonic acid (8), pristimerin (10), abruslactone A (11) and $\alpha$-amirin (12). The PCTTs (4), (6) and (8) were esterified to obtain methyl populnonate (5), methyl katotonate (7) and methyl epikatonate (9), respectivaly. Infrared (IR), mass spectrometry (MS) and nuclear magnetic resonance $\left({ }^{1} \mathrm{H}\right.$ and ${ }^{13} \mathrm{C}$ NMR including 2D experiments) were used to elucidate the chemical structure of the compounds (Souza et al., 1990; Vieira Filho et al., 1999; Vieira Filho et al., 2000; Vieira Filho et al., 2001; Cotta et al., 1990; Silva et al., 2002; Zanon et al., 2008).

\section{Antibacterial activity preliminary assays}

Chloroform extract obtained from the bark $(\mathrm{ChE})$ and from the heartwood of the branches (HChE) were submitted to qualitative microbiological tests against wild-type strains of Staphylococcus aureus and Escherichia coli, both sensitive to vancomicin through Bawer \& Kirby disc diffusion method (Bawer and Kirby, 1966) (Table 2).

\section{Minimum inhibitory concentration (MIC) of the extracts}

Through microdilution technique, four samples ( $2 \mathrm{mg} / \mathrm{mL}$ initial concentration) of $A$. populnea extracts were submitted to microbiological assays to determine the growth minimum inhibitory concentration (MIC) of Staphylococcus aureus (ATCC 21027), Proteus 
vulgaris (ATCC 13315), Pseudomonas aeruginosa (ATCC 15442), Escherichia coli (ATCC 10536) and Staphylococcus aureus (MARSA), microorganisms commonly found in human infectious diseases. All experiments were carried out in triplicate and the average rate found was the rate taken in account (Table $3)$.

Evaluation of minimum bactericidal concentration of the extracts

After the MIC have been established, aliquots of the extracts in which growth inhibition was observed were inoculated onto Muller-Hinton agar and incubated at $37^{\circ} \mathrm{C}$, during 24 hours. Each experiment was performed in triplicate and a non-growth in the cultivation conditions showed the minimum bactericidal concentration of the extract (Table 4).

Evaluation of the antibacterial activity of the constituents isolated from $A$. populnea

The PCTTs 1 to 12 (Figure 1) were respectively dissolved in chloroform. Each chloroform solution was impregnated in sterile Whatmann paper discs $(6.0 \mathrm{~mm}$ diameter) to obtain five different PCTT concentrations, after solvent evaporation. Dried discs containing PCTT were deposited on the surface of agar Müller-Hinton previously inoculated with Salmonela typhimurium, Staphylococcus aureus ATCC 25923, Escherichia coli ATCC 25922 or Shigella sonnei ATCC 11060, in according to Bawer \& Kirby method (Bawer and Kirby, 1966). Oxacillin, tetracycline, amoxicillin, clindamycin and chloramphenicol were used as internal standards.

The analysis of the results was done after 24 hours of incubation at $37^{\circ} \mathrm{C}$. The samples that produced inhibition halos equal or superior to $7 \mathrm{~mm}$ were considered active. Each experiment was developed using five Petri plates. Discs were soaked individually with each one of the solvents that were used for the incorporation of the compounds to be tested. After the process of drying, these discs also were submitted to growth inhibition tests to verify possible interferences caused by the presence of residual nonvolatile compound. For these discs, any growth inhibition halo was detected, which demonstrated the purity of the solvents used and the efficiency of the evaporation process.

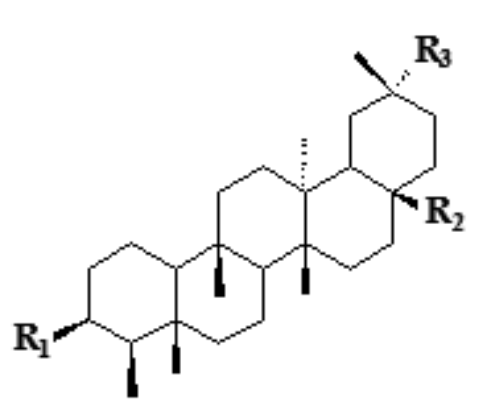

$\begin{array}{cc}\text { Compound } & \mathbf{R}_{1} \\ \mathbf{1} & =\mathbf{O} \\ \mathbf{2} & \text { OH } \\ \mathbf{3} & =\mathbf{O} \\ \mathbf{4} & =\mathbf{O} \\ \mathbf{5} & =\mathbf{O}\end{array}$

$\begin{array}{ccc}\mathbf{R}_{\mathbf{l}} & \mathbf{R}_{2} & \mathbf{R}_{3} \\ \mathrm{O} & \mathrm{H} & \mathrm{H} \\ \mathrm{H} & \mathrm{H} & \mathrm{H} \\ \mathrm{O} & \mathrm{CH}_{2} \mathrm{OH} & \mathrm{H} \\ \mathrm{O} & \mathbf{H} & \mathrm{COOH} \\ \mathrm{O} & \mathrm{H} & \mathrm{COOCH}\end{array}$<smiles>[R1]C1CC[C@]2(C)[C@@H]3CC=C4[C@@H]5C[C@]([R12])(C)CC[C@]5(C)CC[C@]4(C)[C@]3(C)CC[C@@H]2C1(C)C</smiles>
Compound $\quad \mathbf{R}_{1} \quad \mathbf{R 2}_{2}$
$6=\mathrm{O} \quad \mathrm{COOH}$
$7 \quad=\mathrm{O} \quad \mathrm{COOCH}_{3}$
8 OH COOH
$9 \quad \mathrm{OH} \mathrm{COOCH}_{3}$<smiles></smiles><smiles>CC1CCC2(C)CC[C@]3(C)C(=CCC4C5(C)CCC(O)C(C)(C)C5CC[C@]43C)C2[C@@H]1C</smiles>

12

Figure 1. Pentacyclic triterpenes from $A$. populnea submitted to antibacterial activity. 
Table 1. Parts of Austroplenckia populnea and respective extracts used in the antibacterial experiments.

\begin{tabular}{l|l}
\hline \multicolumn{1}{|c|}{ Parts of Austroplenckia populnea } & Extracts submitted to antibacterial assays \\
\hline \multirow{2}{*}{ Leaves } & Hexanic (LHE) \\
& Ethanol (LEE) \\
\hline \multirow{3}{*}{ Branches } & Chloroformic of bark (ChE) \\
& Chloroformic of heartwood (HChE) \\
& Ethylic-acetate (BEaE) \\
Roots & Butanolic (BBE) \\
& Methanolic (BME) \\
\hline
\end{tabular}

Table 2. Results of the preliminary antibacterial activity tests realized with chloroform extract obtained from bark and heartwood of $A$. populnea branches.

\begin{tabular}{c|c|c}
\hline \multirow{2}{*}{ Material tested } & \multicolumn{2}{c}{ Microorganism } \\
\cline { 2 - 3 } & S. aureus & E. coli \\
\hline ChE & + & - \\
\hline HChE & + & + \\
\hline Vancomicin & + & + \\
\hline$+=$ Showed growth inhibition halo. & & \\
\hline
\end{tabular}

Table 3. Minimum inhibitory concentration (MIC) of the extracts $(\mathrm{mg} / \mathrm{mL})$ obtained from $A$. populnea.

\begin{tabular}{l|c|c|c|c}
\multirow{2}{*}{ Bacteria submitted to tests } & \multicolumn{3}{l}{ Parts of A. populnea } & \multicolumn{2}{l}{ Roots } \\
\cline { 2 - 5 } & Branches bark & BEaE & BME & RME \\
\cline { 2 - 5 } & BBE & nd & nd & nd \\
\hline Escherichia coli (ATCC 10536) & nd & nd & 2 & 1 \\
\hline Pseudomonas aeruginosa (ATCC 15442) & nd & nd & 2 & nd \\
\hline Staphylococcus aureus (MARSA) & 0,5 & 0,5 & 0,5 & nd \\
\hline Staphylococcus aureus (ATCC 21027) & nd & nd & nd & nd \\
\hline Proteus vulgaris (ATCC 13315) & &
\end{tabular}

$\mathrm{E}=$ extract; $\mathrm{B}=$ branches and butanolic; $\mathrm{Ea}=$ ethylic-acetate; $\mathrm{M}=$ methanolic

nd $=$ inhibitory effect not detected in the experimental conditions.

Table 4. Minimum bactericidal concentration (MBC) of the extracts $(\mathrm{mg} / \mathrm{mL})$ obtained from A. populnea.

\begin{tabular}{|c|c|c|c|c|}
\hline \multirow{3}{*}{ Bacteria submitted to tests } & \multicolumn{4}{|c|}{ Extracts of $A$. populnea } \\
\hline & \multicolumn{3}{|c|}{ Branches bark } & Roots \\
\hline & BBE & $\mathrm{BEaE}$ & BME & RME \\
\hline Escherichia coli (ATCC 10536) & nd & nd & nd & nd \\
\hline Pseudomonas aeruginosa (ATCC 15442) & nd & nd & nd & nd \\
\hline Staphylococcus aureus (MARSA) & nd & nd & nd & nd \\
\hline Staphylococcus aureus (ATCC 21027) & nd & 1 & nd & nd \\
\hline Proteus vulgaris (ATCC 13315) & nd & nd & nd & nd \\
\hline
\end{tabular}

$\mathrm{E}=$ extract; $\mathrm{B}=$ butanolic; $\mathrm{Ac}=$ ethylic-acetate; $\mathrm{M}=$ methanolic nd $=$ inhibitory effect not detected in the experimental conditions.

\section{RESULTS AND DISCUSSION}

The antibacterial activity of five pentacyclic triterpenes isolated from Autroplenckia populnea extracts was previously reported in relation to Escherichia coli, Streptococcus faecalis, Staphylococcus aureus, Pseudomonas aeruginosa, Staphylococcus epidermides and Salmonella sp. (Vieira Filho et al., 1999). The results obtained in this work demonstrated that among the studied extracts, four of them, with polar character, also showed antibacterial activity. The butanol (BBE) and ethyl acetate (BEaE) extracts obtained from Austroplenckia populnea branches bark showed activity against $S$. aureus (ATCC 21027). The methanol extract from branches bark (BME) also showed activity against 
Table 5. Antibacterial activity of pentacyclic triterpenes isolated from $A$. populnea.

\begin{tabular}{|c|c|c|c|c|c|c|c|c|}
\hline \multirow[t]{2}{*}{ Compound } & \multicolumn{2}{|c|}{ S. typhimurium } & \multicolumn{2}{|c|}{$\begin{array}{c}\text { S. aureus } \\
\text { (ATCC 25923) }\end{array}$} & \multicolumn{2}{|c|}{$\begin{array}{c}\text { E. coli } \\
\text { (ATCC 259222) }\end{array}$} & \multicolumn{2}{|c|}{$\begin{array}{c}\text { S. sonnei } \\
\text { (ATCC 11060) }\end{array}$} \\
\hline & $\mathrm{C}$ & $\mathrm{H}$ & $\mathrm{C}$ & $\mathrm{H}$ & $\mathrm{C}$ & $\mathrm{H}$ & $\mathrm{C}$ & $\mathrm{H}$ \\
\hline 1 & 650 & nd & 970 & nd & 1080 & nd & 170 & 7 \\
\hline 2 & 700 & nd & 930 & nd & 1030 & nd & 230 & 8 \\
\hline 3 & 930 & nd & 520 & nd & 2250 & 8 & 180 & 9 \\
\hline 4 & 860 & nd & 2080 & nd & 810 & nd & 190 & 7 \\
\hline 5 & 600 & nd & 1620 & nd & 250 & 9 & 270 & 8 \\
\hline 6 & - & - & 1050 & nd & 930 & nd & 1250 & 8 \\
\hline 7 & - & - & 570 & nd & 1430 & nd & 240 & 8 \\
\hline 8 & 630 & nd & 430 & nd & 160 & 7 & 500 & nd \\
\hline 9 & 950 & nd & 1360 & nd & 950 & nd & 250 & 7 \\
\hline 10 & 1010 & nd & 490 & nd & 200 & 10 & 170 & 8 \\
\hline 11 & 650 & nd & 440 & nd & 150 & 10 & 140 & 7 \\
\hline 12 & - & - & 810 & nd & 860 & 8 & 230 & 9 \\
\hline
\end{tabular}

$\mathrm{C}=\mu \mathrm{g}$ of compound;

$\mathrm{H}=$ inhibition halo $(\mathrm{mm})$ of bacteria growth;

nd $=$ not detected and

- = not submitted to the experiments.

None inhibition halo was observed for the solvents used during dilution process.

Inhibition halo observed for standards: Amoxicillin: $30 \mu \mathrm{g}(10 \mathrm{~mm})$; Clindamycin: $28 \mu \mathrm{g}(2 \mathrm{~mm})$; Cloramphenicol: $30 \mu \mathrm{g}$ (mm); Oxacyclin: $29 \mu \mathrm{g}(1 \mathrm{~mm})$; Tetracyclin: $24 \mu \mathrm{g}(30 \mathrm{~mm})$.

S. aureus (MARSA) and S. aureus (ATCC 21027) and inhibited the growth of $P$. aeruginosa (ATCC 15442). The growth of this microorganism also was inhibited by root methanol extract (RME) (Table 3).

The corroboration of antibacterial activity of the vegetable extracts evaluated in this work suggests more accurate phytochemical studies to quantify and identify other biologically active chemical substances, which can be pointed as sources of new antibiotics.

None of the PCTTs (Table 5) showed activity against $S$. typhimurium and $S$. aureus. It can be observed that despite the fact that the chloroform extract obtained from the bark and from the heartwood of the branches showed activity against $S$. aureus (Table 3). When abruslactone A (11) a PCTT isolated from this extract $(200 \mu \mathrm{g} / \mathrm{disc})$ was submitted to a test by plate cavity method, it showed activity against $S$. aureus ATCC 25923 (Vieira Filho et al., 1999).

Salaspermic acid was also isolated from the chloroform extract of the Autroplenckia populnea heartwood of the branches. In according to the literature, this PCTT showed anti-HIV activity (Chen et al., 1992). It allows the premise that the activity of this extract should be due to the presence of this compound, that was not tested in this work, or of other substance found in the plant. The data presented in Table 5, show that all the PCTTs showed activity against Shigella sonnei.

For E. coli it was observed that compounds $3,5,8,10,11$ and 12 showed low activity (Table 5). Compound 10 showed significant activity against $E$. coli. On the other hand, this compound was inactive when tested against $E$. coli ATCC st330/84. It was observed that the strains tested are different, which can justify this difference in antibacterial action answer (Vieira Filho et al., 1999).

The results stimulate the accomplishment of new experiments where new tests must be performed, using other pathogenic bacteria, others PCTTs and respective derivatives in order to establish chemical structure versus antibacterial activity correlations.

\section{ACKNOWLEDGEMENTS}

The authors thank the Conselho Nacional de Desenvolvimento Científico e Tecnológico (CNPq) and Fundação de Amparo a Pesquisa de Minas Gerais (FAPEMIG) for financial support. 


\section{REFERENCES}

Agra MF, Silva KN, Basílio IJLD, França PF, Barbosa-Filho JM 2008. Survey of medicinal plants used in the region Northeast of Brazil. Rev Bras Farmacogn 18: 472508 .

Antunes RMP, Lima EO, Pereira MSV, Câmara CA, Arruda TA, Catâo RMR, Barbosa TP, Nunes XP, Dias CS, Silva TMS 2006. Atividade antimicrobiana "in vitro" e determinação da concentração inibitória mínima (CIM) de fitoconstituintes e produtos sintéticos sobre bactérias e fungos leveduriformes. Rev Bras Farmacogn 16: 517-524.

Barbosa-Filho JM, Vasconcelos THC, Alencar AA, Batista LM, Oliveira RAG, Guedes DN, Falcão HS, Moura MD, Diniz, MFFM, Modesto-Filho J 2005. Plants and their active constituents from South Central and North América with hypoglycemic activity. Rev Bras Farmacogn 15: 392-413.

Bawer AW, Kirby WM 1966. Antibiotic susceptibility. Testing by a standardized single disk method. Am J Clin Pathol 45: 493.

Brandão MGL, Cosenza GP, Moreira RA, Monte-Mor RLM 2006. Medicinal plants and other botanical products from the Brasilian Official Pharmacopoeia. Rev Bras Farmacogn 16: 408-420.

Cardoso HT, Santos ML 1948. Estudos sobre a presença de antibióticos nos vegetais. Rev Sem Med Cirur 62: 9-12.

Cardoso-Lopes EM, Carreira RC, Agripino DG, Torres LMB, Cordeiro I, Bolzani VS, Dietrich SMC, Young MCM 2008. Screening for antifungal, DNA-damaging and anticholinesterasic activities of Brazilian plants from the Atlantic Rainforest - Ilha do Cardoso State Park. Rev Bras Farmacogn 18 (Supl.): 655-660.

Chen K, Shi Q, Kashiwada Y 1992. Salaspermic acid, an anti-HIV principles from Trypterygium wilfordii, and the strucute-acitivity correlation with its related compounds. J Nat Prod 55: 340-346.

Correa MP 1969. Dicionário das Plantas Úteis do Brasil V Ministério da Agricultura, RJ: 152 p.

Cotta AB, Mascarenhas YP, Silva GDF, Souza JR 1990a. Structure of a triterpene extracted from Austroplenckia polpunea (Celastraceae), Methyl-3-hidroxy-2-oxo-

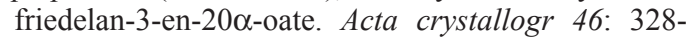
329.

Cotta AB, Mascarenhas YP, Silva GDF, Souza JR 1990b. Structure of a triterpene extracted from Austroplenckia polpunea (Celastraceae), Methyl-3-oxo-friedelan200-oate. Acta Crystallogr 46: 326-327.

Deena MJ, Thoppil JE 2000. Antimicrobial activity of the essential oil of Lantana camara. Fitoterapia 71: 453455.

Duarte LP, Vieira Filho SA, Silva GDF, Pinto AS 2002. Antitrypanosomal activity of pentacyclic triterpenes isolated from Austroplenckia polpunea (Celastraceae). Rev Inst Med Trop São Paulo 44: 109-112.

Gnan SO, Demello MT 1999. Inhibition of Staphylococcus aureus by aqueous goiaba extracts. $J$ Ethnopharmacol 68: 103-108.

Gonzalez JG, Delle Monache G, Delle Monache F, MariniBettolo GB 1982. Chuchuaska - A drug used in folk medicine in the Amazonic and Andean areas. A chemical study of Maytenus laevis. J. Ethnopharmacol 5: 73-77.

Hernandez NE, Tereschuk ML, Abdala LR 2000. Antimicrobial activity of flavonoids in medicinal plants from Tafi del Valle (Tucuman, Argentina). J Ethnopharmacol 73:
317-322.

Kinghorn AD, Balandrin MF 1993. Human Medicinal Agents from Plants. Am Chem Soc Washington. D. C. USA.

Lima MRF, Ximenes CPA, Luna JS, Sant'Ana AEG 2006. The antibiotic activity of some brazilizan medicinal plants. Rev Bras Farmacogn 16: 300-306.

Mazaro R, Di Stasi LC, Vieira Filho SA, Kempinas,WG 2000. Decrease in sperm number after treatment of rats with Austroplenckia polpunea. Contraception 62: 45-50.

Monache FD 1972. Populnonic acid, a new triterpenic acid with friedelane carbon skeleton. Gazz Chim Italian 102: 636-646.

Mors WB, Rizzini CT, Pereira NA 2000. Medicinal Plants of Brazil. Michigan: Reference Publications Inc.

Quintans-Júnior LJ, Almeida JRGS, Lima JT, Nunes XP, Siqueira JS, Oliveira LEG, Almeida RN, Athayde-Filho PF, Barbosa-Filho JM 2008. Plants with anticonvulsant properties - a review. Rev Bras Farmacogn 18 (Supl.): 798-819.

Rao KS 1996. Antibacterial activity of some medicinal plants of Papua New Guinea. Int J Pharmacogn 34: 223-225.

Silva GDF, Duarte LP, Vieira Filho SA, Doriguetto AC, Mascarenha YP, Ellena J, Castellano EE, Costa AB 2002. Epikatonic acid from Austroplenckia populnea: structure elucidation by 2D NMR spectroscopy and X-ray crystallography. Magn Reson Chem 40: 366370.

Souza JR, Janoti NK, Silva GDF, Pinheiro JA 1988. Friedelene triterpene related to populnonic acid. Gazz Chim Italian 118: 821-822.

Souza JR, Silva GDF, Pedersoli JL, Alves RJ 1990. Friedelane and olenane triterpenoids from bark wood of Austroplenckia polpunea. Phytochemistry 29: 32593261.

Tavares-Dias M, Grandini AA 1999. Prevalence and epidemiological aspects of parasitic infestation in the population of São José da Bela Vista, São Paulo State. Rev Soc Bras Med Trop São Paulo 32: 63-65.

Vichnewski W, Prasad JS, Herz W 1984. Polyhydroxyagarofuran derivatives from Austroplenckia polpunea. Phytochemistry 23: 1655-1657.

Vieira Filho SA, Lanna MCS, Paes HCS, Silva GDF, Sousa JR 1999. Antibacterial activity of pentacyclic triterpenes from Austroplenckia populnea. Acta Horticulturae 501: 199-203.

Vieira Filho SA, Duarte LP, Silva GDF, Lula IS, dos Santos MH 2000. Complete assigment of the ${ }^{1} \mathrm{H}$ and ${ }^{13} \mathrm{C}$ NMR spectra of a new polyester sesquiterpene from Austroplenckia populnea. Magn Reson Chem 38: 1023-1026.

Vieira Filho SA, Duarte LP, Silva GDF, Lula IS, Santos MH 2001. Total assignment of ${ }^{1} \mathrm{H}$ and ${ }^{13} \mathrm{C}$ NMR spectra of two 3,4-secofriedelanes from Austroplenckia polpunea. Magn Reson Chem 39: 746-748.

Zanon RB, Pereira DF, Boschetti TK, Santos M, Athayde ML 2008. Fitoconstituintes isolados da fração em diclorometano das folhas de Vernonia tweediana Baker. Rev Bras Farmacogn 18: 226-229. 